\title{
Whole blood transfusion in small animals: indications and effects
}

\author{
LUÍS F. GODINHO-CUNHA ${ }^{1}$, RUI M.R.F. FERREIRA ${ }^{2}$ and ANA C. SILVESTRE-FERREIRA ${ }^{1}$ \\ ${ }^{1}$ Departamento de Ciências Veterinárias, Hospital Veterinário, Universidade de Trás-os-Montes e Alto Douro \\ Quinta de Prados, 5001-801 Vila Real, Portugal \\ ${ }^{2}$ Hospital Veterinário do Porto, Tv. Silva Porto, 174, 4250-475 Porto, Portugal
}

Manuscript received on October 27, 2009; accepted for publication on September 30, 2010

\begin{abstract}
Transfusion therapy is a major resource that can improve the patient's capability to overcome the underlying disease. However, the effects of whole blood infusion, and how they affect the patient's outcome, are not yet clear. For this study, a protocol was developed in order to monitor a group of 15 animals ( 9 dogs, 6 cats) that received a total of 19 transfusions; 3 animals received more than one transfusion each. The most common indications for blood transfusion included acute blood loss (47\%), coagulopathy (33\%) and other anaemias $(20 \%)$. The mean pre-transfusion packed cell volume (PCV) of animals with acute blood loss (18\%) was higher than in the group of coagulopathy $(15 \%)$ or other anaemias (15\%). The survival rates at 6 days after transfusion were greater in the coagulopathy $(80.0 \%)$ and other anaemias $(66.7 \%)$ than in the group of acute blood loss $(42.9 \%)$. After transfusion, pulse rate $(p<0.01)$ and platelet count $(p<0.05)$ decreased significantly, and there was a significant increase in body temperature of the animals that suffered from hypothermia before the transfusion $(p<0.05)$. Overall survival was predictable based upon posttransfusion body temperature, observed PCV change, the difference between the obtained and the calculated PCV, and administered transfusion volume $(p<0.05)$.
\end{abstract}

Key words: transfusion effects, hemotherapy, whole blood, blood transfusion.

\section{INTRODUCTION}

Red blood cell (RBC) transfusions have become an important tool in veterinary critical care and emergency medicine (Weingart et al. 2004). A strict transfusion policy, with the use of blood typing and crossmatching procedures, and careful monitoring, minimize the risk of an adverse reaction and maximize the benefits of transfusion. Fresh whole blood (WB) is composed of RBCs, white blood cells (WBCs), platelets, all the coagulation factors, albumin and immunoglobulins (Chiaramonte 2004). After 6 hours of storing, platelets, factor V, VIII and vWF become depleted (Abrams-Ogg 2000). WB is indicated when several blood components are required or when the patient has acutely lost more than

Correspondence to: Ana Cristina Silvestre Ferreira

E-mail: aferreir@utad.pt
$50 \%$ of its total blood volume, in order to increase oncotic pressure and reestablish tissue oxygenation (Lanevschi and Wardrop 2001). There are some studies concerning the indications and efficacy of whole blood transfusion in dogs and cats (Callan et al. 1996, GriotWenk and Giger 1995, Weingart et al. 2004, Stone et al. 1992, Roux et al. 2008), although very few succeeded in establishing a relation with the outcome. A recent survey clarified the effects of blood collection in cats (Iazbik et al. 2007), but, so far, some of the effects of whole blood infusion in patients are still unknown. The main goal of this study was to clarify the effects of whole blood infusion in dogs and cats in regard of pulse rate, respiratory rate, rectal temperature, blood pressure, platelet count and PCV; and establish an association with the outcome. 


\section{MATERIALS AND METHODS}

From October 2008 until March 2009, 19 whole blood transfusions were monitored; these transfusions were applied to 15 animals (9 dogs and 6 cats) at Hospital Veterinário do Porto (HVP). All procedures were carried out according to the international practices for animal use and care under the control of an internal committee of the HVP. The blood was collected from animals included in the hospital blood donor program. All dog donors were tested for vector borne diseases like Dirofilaria sp., Ehrlichia canis, Babesia canis and Leishmania sp., while cats were tested for FIV, FeLV and Mycoplasma haemofelis infection. Closed collection systems were used in the dog, and open collection systems in the cat. A gel column technique (DiaMedID, DiaMed, Cressier sur Morat, Switzerland) was used for blood typing donors; recipients were used for DEA 1.1 antibody in the dog, and $\mathrm{A}$ and $\mathrm{B}$ antibodies in the cat. A simplified major crossmatch procedure detected possible antibodies in the plasma of the recipient against donor RBCs: 3 glass tubes, containing $0.1 \mathrm{~mL}$ of serum or plasma of the recipient and $0.1 \mathrm{~mL}$ of a $4 \%$ suspension of donor $\mathrm{RBCs}$, were incubated at $4^{\circ} \mathrm{C}, 25^{\circ} \mathrm{C}$ and $37^{\circ} \mathrm{C}$ for 15 minutes, and then examined for hemolysis and hemoaglutination. Animals were only transfused with compatible blood after blood typing and crossmatch.

A protocol was created in order to monitor the patient before, during and after transfusion. Attitude, pulse, respiratory rate, mucous membranes and rectal temperature were monitored before the transfusion at every 5 minutes in the first 20 minutes, 40 minutes, 1 hour, 2 hours and 12 hours after the beginning of transfusion. A complete blood count (equipment: Auto Hematology Analyzer BC-2800Vet, Mindray) and blood pressure measurements using a High Definition Oscillometric system (equipment: MemoDiagnostic, $\mathrm{S}+\mathrm{B}$ medVET) were made 2 hours and 12 hours after the beginning of transfusion. Symptoms of acute and delayed transfusion reactions were investigated. The volume of blood to be administered to the patient was calculated using the following formula:

$$
\begin{gathered}
\text { Volume }(\mathrm{mL})=\text { Recipient weight }(\mathrm{Kg}) \\
\times{ }_{66^{(\mathrm{cat})}}^{88^{(\mathrm{dog})}} \times \frac{(\text { Recipient desired PCV-Current PCV })}{\text { PCV of donor blood }}
\end{gathered}
$$

However, the transfusion volume was frequently smaller than the desired because of the limited amount of blood available from one donor. Multiple transfusions were avoided in order to decrease the risk for transfusion reactions, but also because of economical restrains presented by the owners. The desired or expected PCV was considered to be $10 \%$ higher than the patient's $\mathrm{PCV}$ before transfusion. The transfusion rate was $0.25 \mathrm{~mL} / \mathrm{Kg} / \mathrm{h}$ in the first 20 minutes, and then increased to $5-10 \mathrm{~mL} / \mathrm{Kg} / \mathrm{h}$. Patients with heart conditions were transfused at a smaller rate, and hipovolemic animals without further complications at a superior rate. The blood units storing time was recorded in the patient's monitoring protocol. The outcome was defined as survival to hospital discharge or death/euthanasia.

Descriptive statistics were used to report the results of age and weight, PCV before and after transfusion, blood units storing time, transfusion volume, the difference between the obtained and the expected posttransfusion PCV, and the difference between pre- and post-transfusion PCV (PCV variation). A paired student's $t$ test was used to compare pulse rate, respiratory rate, rectal temperature, mean arterial pressure (MAP), platelet count and PCV before and 12 hours after transfusion. Linear regression was performed to relate blood storing time and transfusion volume with PCV variation. One-way ANOVA was applied using PCV variation, the difference between the obtained and the expected $\mathrm{PCV}$, and transfusion volume as independent variables; and the outcome (dead or alive) as the dependent variable. The animals were primarily grouped according to physiologic mechanism of anaemia (acute blood loss, coagulopathy or other anaemias) and later grouped together. Multiple transfusions were analyzed as separate transfusion episodes (TE). SPSS $17.0^{\circledR}$ was used for statistical analysis. Dogs and cats were included in the same group, since the variables proved to be independent from species. Values of $p<0.05$ were considered significant.

\section{RESULTS AND DISCUSSION}

In this study, $60 \%(n=9)$ of the animals were dogs and $40 \%(n=6)$ were cats. Table I resumes the data from the 15 animals included in this study. One dog was blood type DEA 1.1 negative, while the rest was 
TABLE I

Data from the 15 animals included in this study: weight, breed, sex, age, blood type, number of transfusions, transfusion indication (ABL, acute blood loss; C, coagulopathy; OA, other anaemias), pre- and post- PCV, and outcome.

\begin{tabular}{|c|c|c|c|c|c|c|c|c|c|c|}
\hline Animal & $\begin{array}{c}\text { Weight } \\
(\mathrm{Kg})\end{array}$ & Breed & Sex & $\begin{array}{c}\text { Age } \\
\text { (years) }\end{array}$ & $\begin{array}{l}\text { Blood } \\
\text { type }\end{array}$ & $\begin{array}{l}\text { Number of } \\
\text { transfusions }\end{array}$ & Indication & \multicolumn{2}{|c|}{ PCV pre post } & \multirow{2}{*}{$\frac{\text { Outcome }}{\text { Dead }}$} \\
\hline $\operatorname{Dog} 1$ & 65.85 & Grand Danois & $\mathrm{F}$ & 6 & $1.1+$ & 1 & $\mathrm{ABL}$ & 28.6 & 25.9 & \\
\hline $\operatorname{Dog} 2$ & 26.40 & Pit Bull & $F$ & 10 & $1.1+$ & 1 & $\mathrm{C}$ & 25.7 & 25.1 & Alive \\
\hline $\operatorname{Dog} 3$ & 23.75 & Pointer & F & 7 & $1.1+$ & 1 & $\mathrm{ABL}$ & 16.0 & 35.8 & Alive \\
\hline $\operatorname{Dog} 4$ & 57.00 & Saint Bernard & $M$ & 10 & $1.1+$ & 1 & $\mathrm{OA}$ & 20.5 & 20.7 & Alive \\
\hline Dog 5 & 27.60 & Siberian Husky & $\mathrm{F}$ & 3 & $1.1+$ & 1 & $\mathrm{C}$ & 12.2 & 17.6 & Alive \\
\hline $\operatorname{Dog} 6$ & 41.15 & Grand Danois & $F$ & 3 & $1.1+$ & 1 & $\mathrm{OA}$ & 11.3 & 20.1 & Alive \\
\hline \multirow[t]{2}{*}{$\operatorname{Dog} 7$} & 3.50 & Pinscher & $\mathrm{M}$ & 8 & $1.1-$ & 2 & $\mathrm{C}$ & 8.1 & 28.4 & Alive \\
\hline & & & & & & & & 17.9 & 26.1 & \\
\hline $\operatorname{Dog} 8$ & 10.00 & Labrador & $\mathrm{M}$ & 0.2 & $1.1+$ & 1 & $\mathrm{ABL}$ & 29.4 & 29.4 & Dead \\
\hline $\operatorname{Dog} 9$ & 4.60 & Undetermined & $\mathrm{F}$ & 4 & $1.1+$ & 1 & $\mathrm{ABL}$ & 15.8 & 35.1 & Alive \\
\hline \multirow[t]{3}{*}{ Cat 1} & 5.50 & Siamese & M & 2 & $\mathrm{~A}$ & 3 & $\mathrm{C}$ & 19.4 & 17.0 & Dead \\
\hline & & & & & & & & 13.6 & 14.0 & \\
\hline & & & & & & & & 11.0 & 9.9 & \\
\hline Cat 2 & 5.60 & DSH & $\mathrm{M}$ & 11 & $\mathrm{~A}$ & 1 & $\mathrm{ABL}$ & 11.9 & 18.7 & Dead \\
\hline \multirow[t]{2}{*}{ Cat 3} & 3.50 & Persian & $\mathrm{F}$ & 1 & $\mathrm{~A}$ & 2 & $\mathrm{ABL}$ & 12.6 & 20.6 & Alive \\
\hline & & & & & & & & 13.3 & 16.2 & \\
\hline Cat 4 & 3.40 & $\mathrm{DSH}$ & $\mathrm{M}$ & 4 & $\mathrm{~A}$ & 1 & $\mathrm{C}$ & 13.3 & 16.2 & Alive \\
\hline Cat 5 & 4.00 & DSH & M & 0.7 & A & 1 & $\mathrm{ABL}$ & 18.2 & 17.0 & Dead \\
\hline Cat 6 & 2.55 & DSH & $\mathrm{F}$ & 23 & A & 1 & $\mathrm{OA}$ & 14.5 & 21.0 & Dead \\
\hline
\end{tabular}

positive for this antigen. All cats were blood type A. The median age was 5.6 years, with a range of 0.7 to 23 years. The weight ranged between 2.6 and $5.6 \mathrm{Kg}$ in cats, and 3.5 and $65.9 \mathrm{Kg}$ in dogs. Of 19 transfusions, 10 were administered to dogs and 9 to cats. Twelve patients $(80.0 \%)$ received only one transfusion, two $(13.3 \%)$ were transfused twice and one $(6.7 \%)$ received three transfusions. A total of $52.6 \%$ of the 19 blood transfusions had a severe anaemia $(\mathrm{PCV}<$ $15 \%), 26.3 \%$ had a moderate anaemia (PCV 15-20\%), and the remaining $21.1 \%$ had a light anaemia $(\mathrm{PCV}>$ $20 \%$ ). A study in feline patients also reported severe anaemia to be the leading indication for transfusion (Weingart et al. 2004). There is a high percentage of animals being transfused because of severe anaemia. This may indicate that blood is more commonly transfused because of long-term chronic diseases in which the PCV has lowered to critical values. Another possibility is that a high number of transfusions are being applied because of acute onset diseases after the attempt to stabilize the animal through intensive fluid therapy, which allows the PCV to decrease.

The indications for transfusion included acute blood loss $(n=7 ; 47 \%)$, coagulopathies $(n=5 ; 33 \%)$ and other causes of anaemia $(n=3 ; 20 \%)$. The percentage of animals with acute blood loss is higher than previously obtained by Callan et al. (1996) (33\%) in dogs, and similar to what Stone et al. (1992), Weingart et al. (2004) and Klaser et al. (2005) found in a group of 60 dogs (45\%), 91 cats (44\%) and 126 cats (52\%), respectively. Figure 1 shows the patient's PCV before and 12 hours after the beginning of transfusion, according to transfusion indication. Previous studies also reported a higher pre-transfusion PCV in the acute blood loss group compared to other groups (Griot-Wenk and Giger 1995, Callan et al. 1996). On the one hand, this may reflect the clinician's hesitation to administer RBCs to animals with coagulopathies and other anaemias, such as chronic severe diseases or hemolytic disturbances. On the other hand, when blood loss is acute, 
there is no time for the body to adapt physiologically to a lower PCV, requiring transfusion support at higher PCVs (Callan et al. 1996). In our study, these results may indicate that the clinician's decision to transfuse an animal with acute blood loss was made in time, based on the patient's symptoms more than on its PCV. Even though most of these animals were submitted to intensive fluid therapy, transfusion seemed to happen in the early hours, before hemodilution effects took place. Figure 2 shows the survival rates at day 1, 3 and 6 posttransfusion, on each etiologic group. The study carried out by Callan et al. (1996) also revealed a smaller short-term survival rate in dogs with hemorrhage, despite showing a higher post-transfusion PCV. In her study, the main causes of hemorrhage were trauma, surgery, neoplasia, thrombocytopenia, and gastrointestinal bleeding, among others. In our study, acute blood loss was secondary to trauma, surgery and neoplasia. In both studies, the causes for transfusion were similar. Callan et al. (1996) explained the smaller short-term survival based on the severe underlying diseases and the inability to stabilize some of the patients included in this group. We believe that this also explains our results.

Respiratory rate, rectal temperature and MAP increased after transfusion, although not significantly. Figure 3 shows the most significant changes following blood infusion. Pulse rate decreased significantly after transfusion. Patients with acute anaemias have a compromised oxygen-carrying capacity, presenting different states of hypoxia or anoxia (Carson and Hébert 2009). The body tries to increase oxygen delivery to vital organs by activating the sympathetic and adrenergic nervous systems, which increases heart rate and cardiac output (Carson and Hébert 2009). When these patients receive a RBC transfusion, blood volume and oxygen-carrying capacity are reestablished. This normalizes heart rate and, therefore, decreases pulse rate.

Even though there was a significant PCV increase after transfusion, platelet count decreased significantly. In fact, we registered a moderate to severe thrombocytopenia in 11 transfusions episodes, with platelet count ranging from 15 to $100 \times 10^{9} / \mathrm{L}$. This phenomenon is consistent with the findings of Jutkowitz et al. (2002) in a retrospective study on massive transfusions in dogs. The mechanism by which thrombocytopenia develops

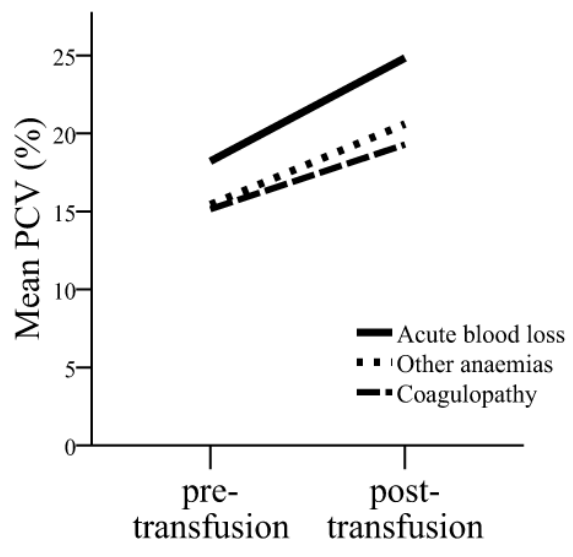

Fig. 1 - Mean PCV before and 12 hours after the transfusion, according to transfusion indication: acute blood loss $(n=8 \mathrm{TE})$, other anaemias ( $n=3 \mathrm{TE})$ and coagulopathy $(n=8 \mathrm{TE})$.

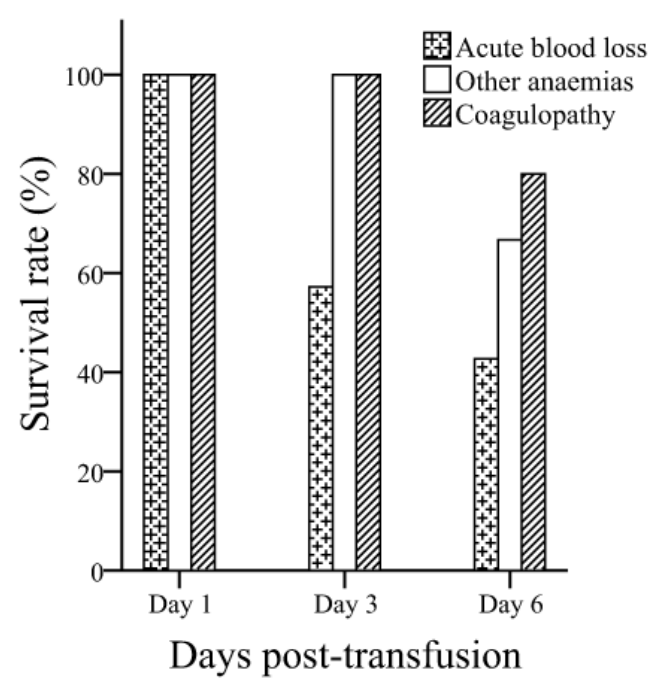

Fig. 2 - Survival rates at day 1, 3 and 6 post-transfusion on each etiologic group.

is multifactorial, although the most important cause seems to be hemodilution caused by intensive fluid therapy and infusion of platelet-poor blood (stored for over 6 hours) (Jutkowitz et al. 2002). All blood units used in this study were stored for over 6 hours; storing time varied between 0 and 30 days ( $m=12$ days). Since platelets become depleted soon after blood collection we assume that the blood infused to our patients was platelet-poor. This explains the lower post-transfusion platelet count and the thrombocytopenia.

When animals were grouped all together, there was no significant increase of post-transfusion rectal temperature comparing to pre-transfusion values. However, 

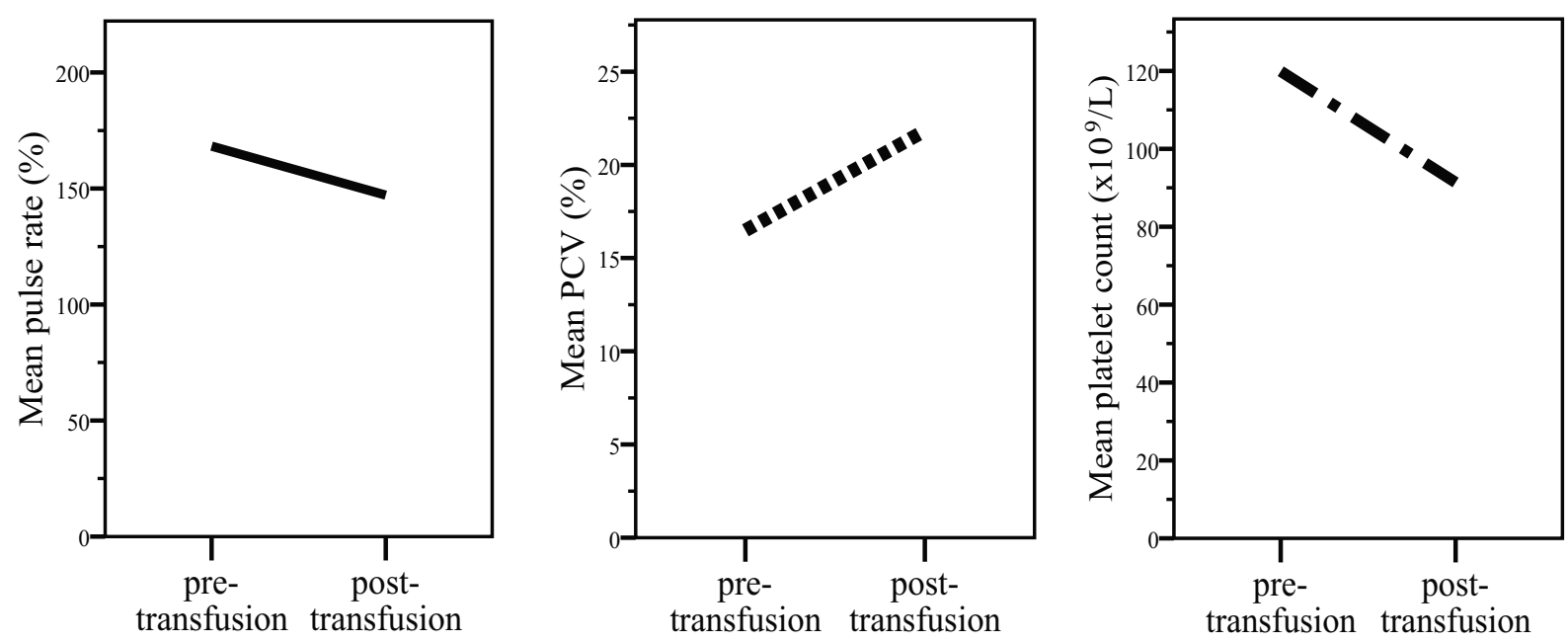

Fig. 3 - Variations of mean pulse rate (A), mean PCV (B) and mean platelet count (C) before and $12 \mathrm{~h}$ after beginning of transfusion $(n=19 \mathrm{TE})$.

when we isolated and grouped animals presenting pretransfusion hypothermia (10 out of 19 transfusion episodes), we found relevant information. After transfusion, the mean rectal temperature of these animals was considered normal $\left(37.5 \pm 1.2^{\circ} \mathrm{C}\right)$. This could be a consequence of successful transfusion therapy and correction of hypovolemia. Moreover, before transfusion, the mean rectal temperature in the 9 survivors $(37.4 \pm 1.4)$ was similar to the 6 non-survivors $(37.0 \pm 1.9)$. Nevertheless, 12 hours after the transfusion, the rectal temperature of the non-survivors $\left(37.1 \pm 1.1^{\circ} \mathrm{C}\right)$ was $1{ }^{\circ} \mathrm{C}$ lower than the survivors' $\left(38.2 \pm 0.9^{\circ} \mathrm{C}\right)$, indicating that this variable is significantly related to the outcome $(p=0.035)$.

A rise in PCV was documented after 13 transfusions, a decline was seen after five, and in one case there was no change. Decreases in PCV are not rare and have been described before (Weingart et al. 2004). Causes for this phenomenon include hemodilution by crystalloid fluids and persistence of the primary cause (blood loss or hemolysis) (Rozanski and Laforcade 2004). PCV variation ranged between -2.7 and $20.3 \%$ $(m=5.3)$ and was related with the outcome ( $p=$ 0.018). Klaser et al. (2005) found a similar PCV increase $(6.4 \pm 3.9 \%)$ in a group of 126 cats. Mean PCV variation of animals that survived to hospital discharge ( $m=8.7 \%$ ) was 10 times higher than that of the nonsurvivors ( $m=0.8 \%$ ) (Fig. 4). Roux et al. (2008) found no relation between these two variables in their study.
As far as we know, our study is the first one to find a statistically significant relation between PCV variation and survival in veterinary patients. This might indicate that transfusion is more efficient in some animals than in others. Patients with more efficient transfusions achieved higher PCVs and had better oxygen-carrying capacity to overcome the underlying disease. In patients in which the transfusion was less efficient, lower PCV values might have perpetuated hypoxia, holding back recovery and increasing mortality. Acute blood loss patients are the exception, as they have a high but unreal PCV as a consequence of total blood loss. This is the reason why acute blood loss patients had high PCV, but also high mortality.

Surprisingly, our study shows that the animal with lower pre-transfusion PCV had the most evident PCV increase. The volume of blood applied proved to be significantly related to PCV variation. So, we presume that different transfusion efficacy may be attributable to the amount of blood applied to a patient in a single transfusion.

The difference between the post-transfusion PCV and the expected one ranged between -12.7 and $+10.3 \%(m=-4.5)$. This tells us that the mean posttransfusion $\mathrm{PCV}$ was $4.5 \%$ lower than what would be expected for the animal. It may indicate a persistence of blood loss or hemolysis, although we cannot exclude hemodilution. Three animals had a post-transfusion PCV 10\% higher than what would be expected. 
Possible reasons for this results include reabsorptive mechanisms from cavity bleedings, splenic contraction and dehydration (Weingart et al. 2004). Obtained posttransfusion PCV values were below the expected, particularly in the animals that died. So, the difference between the obtained and the expected PCV was considered a significant prognostic factor $(p=0.013)$.

Blood units storing time varied between 0 and 30 days ( $m=12$ days). No significant relation was found between blood storing time and PCV variation ( $p=$ 0.396). Unfortunately, there wasn't enough data to relate blood storing time with other adverse effects like hemoglobinuria, fever or icterus.

In this study, the mean transfusion volume was $15 \mathrm{~mL} / \mathrm{Kg}$ (range $7-28 \mathrm{~mL} / \mathrm{Kg}$ ). This is lower than the previously documented in dogs $(25 \mathrm{~mL} / \mathrm{Kg})$, and higher than what was described in cats $(7 \mathrm{~mL} / \mathrm{Kg})$ (Weingart et al. 2004, Callan et al. 1996). Transfusion volume influenced PCV variation significantly ( $p=0.001)$, and this relation can be defined by the following formula:

$$
\begin{gathered}
\text { PCV variation }(\%)=0.8 \\
\times \text { transfusion volume }(\mathrm{mL})-6.954
\end{gathered}
$$

This means that the infusion of $20 \mathrm{~mL} / \mathrm{Kg}$ of whole blood increases patients' PCV by $9.1 \%$. It is generally considered that the infusion of this volume of whole blood is followed by a $10 \%$ PCV increase (Kristensen and Feldman 1995). Apparently, the results obtained in our study are similar and consistent with these guidelines. Survivors were transfused with a mean volume $(19 \pm 6 \mathrm{~mL} / \mathrm{Kg})$ that is significantly higher ( $p=0.010)$ than the transfusion volume of the nonsurvivors (11 $\pm 4 \mathrm{~mL} / \mathrm{Kg}$ ) (Fig. 4).

Overall, nine patients $(60 \%)$ were discharged from the hospital. As for the remaining, 5 (83\%) died and 1 (17\%) was euthanized. This survival rate is similar to the documented rate in previous studies (Callan et al. 1996, Kerl and Hohenhaus 1993, Weingart et al. 2004, Roux et al. 2008, Klaser et al. 2005).

In conclusion, this study is limited by the small number of animals involved and simultaneous analysis of cats and dogs, which made impossible to determine the transfusion effects in each species. The small and heterogeneous studied population may lead to inevitable miscalculations, and further studies should be undertaken to reinforce our conclusions. However, post-

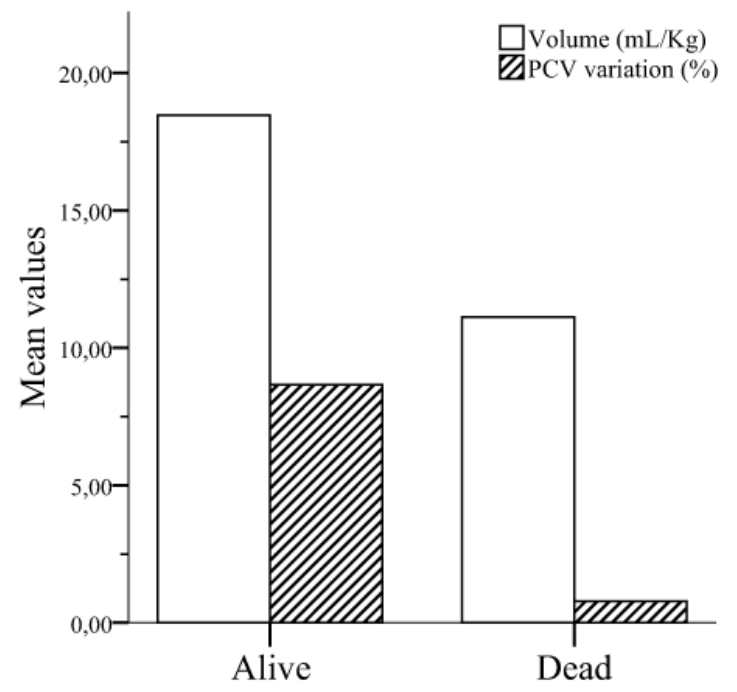

Fig. 4 - Mean transfusion volume (A) and mean PCV variation (B) according to the outcome.

transfusion body temperature, observed PCV change, the difference between the obtained and the calculated $\mathrm{PCV}$, and administered transfusion volume determined overall survival and may function as prognostic factors of transfusion outcome.

\section{ACKNOWLEDGMENTS}

The authors would like to thank Hospital Veterinário do Porto for the possibility to elaborate this study.

\section{RESUMO}

A terapia transfusional é um importante recurso que pode auxiliar na recuperação do doente face à patologia primária. No entanto, não estão totalmente esclarecidos os efeitos de uma transfusão sanguínea, e que consequências podem ter no desfecho clínico. Para este estudo, foi desenvolvido um protocolo de forma a monitorizar 15 animais ( 9 cães e 6 gatos) que receberam um total de 19 transfusões; 3 animais receberam mais do que uma unidade de sangue. As indicações mais comuns para realização da transfusão foram hemorragia aguda (47\%), coagulopatia (33\%) e outras anemias $(20 \%)$. O hematócrito pré-transfusional médio dos animais com hemorragia aguda (18\%) foi superior ao dos animais com coagulopatia (15\%) ou outras anemias (15\%). A taxa de sobrevivência ao sexto dia pós-transfusão foi maior no grupo da coagulopatia $(80,0 \%)$ e de outras anemias $(66,7 \%)$, do que no grupo da hemorragia aguda $(42,9 \%)$. Após a transfusão, a frequência de pulso $(p<0,01)$ e a contagem de plaquetas $(p<0,05)$ 
diminuíram significativamente, e houve um aumento significativo da temperatura corporal nos animais com hipotermia antes da transfusão $(p<0,05)$. A sobrevivência foi predizível com base na temperatura pós-transfusão, a variação do $\mathrm{Ht}$, a diferença entre o Ht real e o Ht esperado, e o volume de transfusão aplicado $(p<0,05)$.

Palavras-chave: efeitos transfusionais, hemoterapia, sangue inteiro, transfusão sanguínea.

\section{REFERENCES}

Abrams-OGg A. 2000. Practical Blood Transfusion. In: DAY MJ ET AL. (Eds), BSAVA manual of canine and feline haematology and transfusion medicine, Gloucester, U.K.: British Small Animal Veterinary Association, p. $263-307$.

Callan MB, OAKley DA, Shofer FS and Giger U. 1996. Canine red blood cell transfusion practice. J Am Anim Hosp Assoc 32: 303-311.

CARson JL and Hébert P. 2009. Anemia and Red Blood Cell Transfusion. In: SIMON TL ET AL. (Eds), Rossi's principles of transfusion medicine, Oxford: Wiley-Blackwell, p. 131-148.

Chiaramonte D. 2004. Blood-component therapy: selection, administration and monitoring. Clin Tech Small Anim Pract 19: 63-67.

Griot-Wenk ME AND Giger U. 1995. Feline transfusion medicine. Blood types and their clinical importance. Vet Clin North Am Small Anim Pract 25: 1305-1322.

IAZBIK MC, GOMEZ OCHOA P, WeSTENDORF N, CHARSKE J AND COUTO CG. 2007. Effects of blood collection for transfusion on arterial blood pressure, heart rate, and PCV in cats. J Vet Intern Med 21: 1181-1184.
Jutkowitz LA, RozAnski EA, MoReAu JA AND RUSH JE. 2002. Massive transfusion in dogs: 15 cases (19972001). J Am Vet Med Assoc 220: 1664-1669.

Kerl ME And Hohenhaus AE. 1993. Packed red blood cell transfusions in dogs: 131 cases (1989). J Am Vet Med Assoc 202: 1495-1499.

Klaser DA, Reine NJ And Hohenhaus AE. 2005. Red blood cell transfusions in cats: 126 cases (1999). J Am Vet Med Assoc 226: 920-923.

Kristensen AT AND Feldman BF. 1995. General principles of small animal blood component administration. Vet Clin North Am Small Anim Pract 25: 1277-1290.

LANEVSCHI A AND WARDROP KJ. 2001. Principles of transfusion medicine in small animals. Can Vet J 42: 447-454.

Roux FA, Deschamps JY, Blais MC, Welsh DM, DELAFORCADE-BURESS AM AND ROZANSKI EA. 2008. Multiple red cell transfusions in 27 cats (2003-2006): indications, complications and outcomes. J Feline Med Surg 10: 213-218.

RoZANSKI E AND LAFORCADE AM. 2004. Transfusion medicine in veterinary emergency and critical care medicine. Clin Tech Small Anim Pract 19: 83-87.

Stone E, BAdner D And Cotter SM. 1992. Trends in transfusion medicine in dogs at a veterinary school clinic: 315 cases (1986-1989). J Am Vet Med Assoc 200: 10001004.

Weingart C, Giger U And Kohn B. 2004. Whole blood transfusions in 91 cats: a clinical evaluation. J Feline Med Surg 6: 139-148. 